\title{
A ARANHA VIVE DO QUE TECE
}

Arissana Braz Bomfim de Souza ${ }^{1}$

O presente artigo é baseado na minha dissertação de mestrado intitulada "Arte e Identidade: adornos corporais Pataxó", fruto de uma pesquisa etnográfica realizada entre 2010 e 2012, junto ao povo Pataxó do Extremo Sul da Babia. Ele descreve os adereços pataxó, destacando os processos de aprendizagem, produção, comercialização e circulação entre as aldeias, e apresenta também uma pequena mostra da variedade existente.

Palavras-chave: adereços, Pataxó, identidade, arte

\section{O CONTEXto EtNográfico}

Os Pataxó são um povo indígena que, dentre os muitos que habitavam a Bahia no século XVI, resistiu a uma série de tentativas de eliminação física desfechadas desde a chegada dos primeiros europeus ao Brasil. Atualmente, constitui uma população de aproximadamente quinze mil indivíduos distribuídos em trinta e seis aldeias, sendo seis no estado de Minas Gerais, nos municípios de Carmésia (Sede, Retirinho e Imbiruçu); Arassuaí (Aldeia Jundiba); Açucena (Aldeia Jeru Tukumã); e Itapecerica (Aldeia Moãmimati); e trinta no estado da Bahia, concentradas na porção do extremo sul, nos municípios do Prado - Tawá, Cravero, Àguas Belas, Corumbauzinho, Cahy, Alegria Nova, Monte Dourado, Maturembá, Tibá e Pequi ; Itamaraju Trevo do Parque; Porto Seguro - Juerana, Aldeia Velha, Imbiriba, Xandó, Bujigão, Barra Velha, Pará, Campo do Boi, Meio da Mata, Boca da Mata, Cassiana, Pé do Monte, Jitaí, Guaxuma e Aldeia Nova; e Santa Cruz Cabrália - Coroa Vermelha, Aroeira, Mata Medonha e Nova Coroa (Figura 1). Há também famílias pataxós que vivem em áreas urbanas, principalmente nas cidades mais próximas às aldeias.

1 Mestre em Estudos Étnicos e Africanos pela Universidade Federal da Bahia. Professora na Escola Indígena Pataxó Boca da Mata. E-mail: arissana_braz@yahoo.com.br 


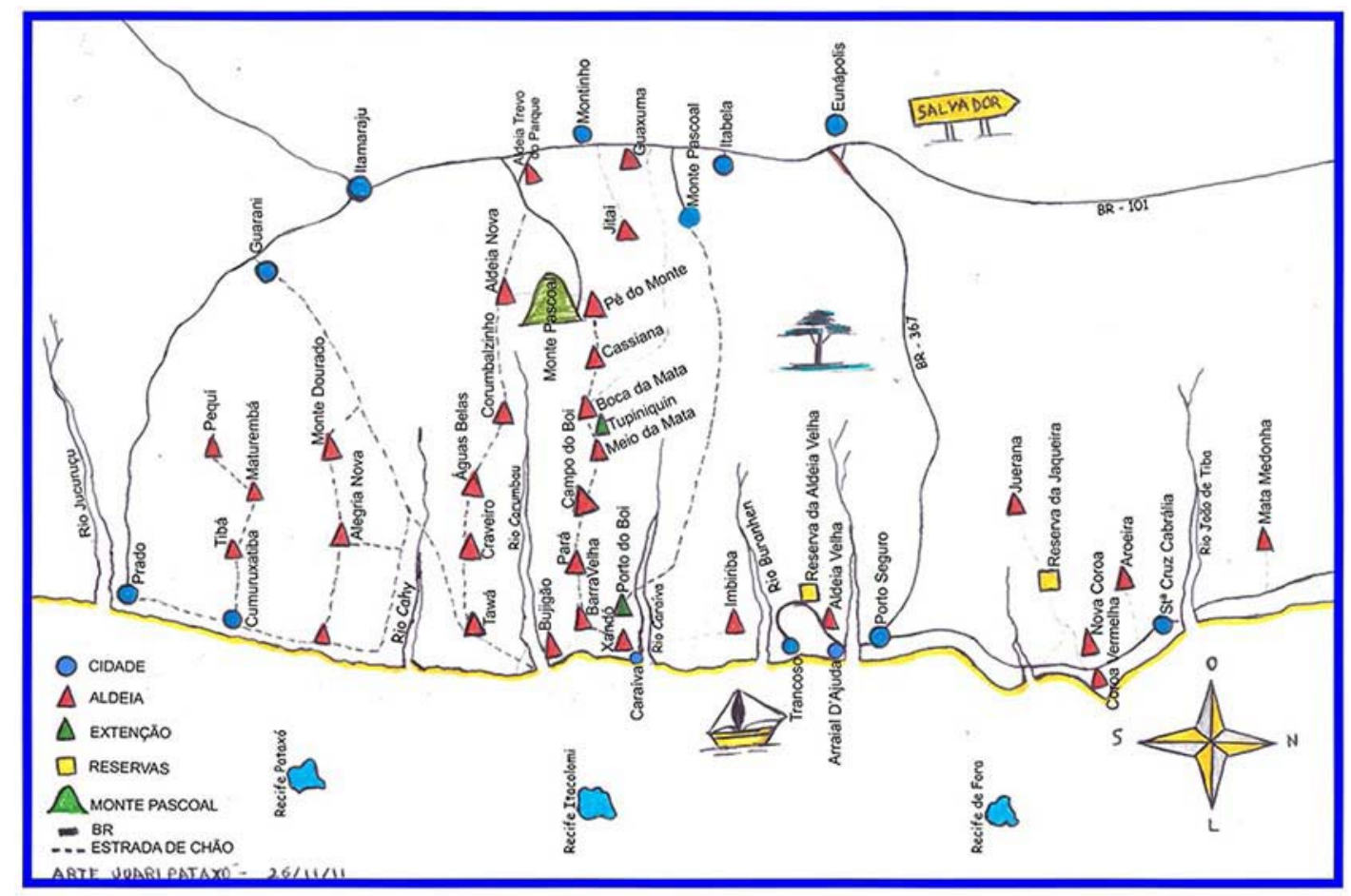

Figura 1. Mapa das aldeias do povo Pataxó localizadas no extremo sul da Bahia. ${ }^{2}$

“Pra gente nunca esquecer o que nossos pais deixaro (...)"

[...] é importante frisar que toda sociedade produz um estilo de ser, que vai acompanbado de um estilo de gostar e, pelo fato de o ser humano se realizar enquanto ser social por meio de objetos, imagens, palavras e gestos, os mesmos se tornam vetores da sua ação e de seu pensamento sobre seu mundo. (Lagrou 2010: 2).

Não obstante constitua um povo que há muito mantém contato com a população não indígena regional, os Pataxós orgulham-se de conservar muitos saberes transmitidos e ensinados pelos mais velhos, dentre os quais estão os adornos corporais, mais conhecidos pelos Pataxó como adereços, que são os cocares, as tangas, as pulseiras, cintos, brincos, braceletes e tornozeleiras, usados por eles em diversos ambientes e para as mais distintas finalidades, tais como nas festas que acontecem nas aldeias, em encontros e eventos internos e externos, em movimentos públicos de manifestação e reivindicação, e também quando comercializam artesanatos.

Foi mediante a transmissão de pai para filho que tanto a produção quanto o uso dos adereços Pataxó foram preservados até os dias atuais. A família exerceu, assim, um papel importante no que se refere ao uso e aprendizagem entre as crianças. E os mais velhos, assim como no passado, continuam sendo os mestres e um referencial para os mais jovens, geralmente os avós, os pais ou mesmo outro familiar mais próximo. Cristiane, professora pataxó da Aldeia Cahy, relata

2 Mapa elaborado por Juari Braz. 
que, quando estava na faixa de sete a oito anos, sua avó Zabelê começou a incentivar a produção e o uso dos adereços entre filhos e netos.

Quando foi um dia ela falou assim: - amanhã eu vou fazer um cauim, um peixe na patioba, e vocês vão vim pra cá que eu vou fazer uma dança lá no quintal. Aí quando foi no outro dia a gente ansioso, fui pra lá. Chegou, Zabelê já tava com um pratão de semente lá no chão né, agulha, aí começou a ensinar a gente fazer, pegar na agulha. Ela falava isso aqui que é artesanato de índio, vocês tem que fazer isso aqui, pra gente nunca esquecer o que nossos pais deixaro pra gente. Aí começou a ensinar. Eu comecei a fazer através desse ensino de Zabelê [...] ela começou a ensinar a dança também pra gente, aí a gente começou a confeccionar os nossos adereços, a tanga, ela levava a gente pra lagoa pra tirar taboa, botava a gente pra fazer o nosso próprio cocar. (informação verbal) $)^{3}$.

Cristiane é, atualmente, professora da Escola Indígena Kijetxawê Zabelêt, coordena o grupo de cultura da Aldeia Cahy e, seguindo o exemplo da avó, confecciona os adereços juntamente com os jovens do grupo, para incentivá-los e ensiná-los, tendo também a ajuda do esposo, da mãe e do cacique da aldeia

Anderson, da Aldeia Tibá, afirma que com a sua avó Zabelê também aprendeu a fazer a maioria dos adereços que confecciona: colar, brinco, pulseira e o cocar tipo coroinha usado mais pelas mulheres. Assim, baseado nos adereços que já produz e em sua habilidade no uso das matérias-primas, não tem dificuldade de aprender a confeccionar outros adereços. Foi assim que aprendeu a confeccionar o cocar de duas tranças elaborado e lançado em Coroa Vermelha: “já aprendi sozinho mesmo, peguei a base do outro e fui. Na verdade eu comprei um em Coroa Vermelha e desse eu comecei a olhar" (informação verbal) ${ }^{5}$. É desse modo que muitos Pataxó também aprendem, observando e reproduzindo um determinado adereço, sem necessariamente ter alguém intermediando o processo.

Há também outros contextos que favorecem tanto a aprendizagem quanto a troca de adereços entre os Pataxó. Estou referindo aos encontros, reuniões, cursos e até retomadas de parcelas do território indígena. Voltairis, da Aldeia Pequi, relata que aprendeu a fazer muitos adereços com seu avô, inclusive a tanga da biriba, ao passo que aprendeu a fazer o cocar

numa época de uma retomada lá nos eucalipto, ali perto do Guaxuma. [...] já aprendi com um parente lá da Aldeia Guaxuma né, eu vi ele fazendo, ele tava ensinando lá a gente, aí eu aprendi o processo. Assim, com ele lá eu aprendi só o processo de tá amarrando as pena né no barbante. Aí, já aprendi a colocar na trança os bordado com os parente de Coroa Vermelha (informação verbal). ${ }^{6}$

Por outro lado, foi com Gilson, professor da Escola Indígena Pataxó Coroa Vermelha, que concluiu o aprendizado: "[...] foi quando ele tava no Magistério ele trazia pra fazer [...] quando tava com algum tempo que ia pros seus apartamentos ficava fazendo. E eu com curiosidade ficava olhando ali, até mesmo perguntava alguma coisa e ele passava informação pra mim.” (informação verbal) ${ }^{7}$.

3 Entrevista concedida por Cristiane Maria de Oliveira Jandaia, 33 anos, em março de 2011, na cidade de Cumuruxatiba - BA.

4 A Escola Kijetxawê Zabelê, com sede na Aldeia Tibá, distribui-se em seis núcleos localizados em aldeias e extensões, na região de Cumuruxatiba. São elas: Aldeia Tibá, Pequi, Cahy, Maturembá (extensão da Tibá), Alegria Nova e Monte Dourado.

5 Entrevista concedida por Anderson Souza Ferreira, 29 anos, durante pesquisa de campo em janeiro de 2011, na cidade de Cumuruxatiba - BA.

6 Entrevista concedida por Voltairis - Irisnan Pataxó-, durante pesquisa de campo na Aldeia Pequi, realizada em fevereiro de 2011.

7 Idem. 
Assim, aprender a fazer os adereços é um dos primeiros passos de um processo de constituição da arte Pataxó, que está intimamente associado com a história e a memória dos mais velhos e com o processo de socialização dos mais jovens, e em estreita convivência com os demais, notadamente com os mais velhos. O exemplo de Zabelê, anteriormente referido, é eloquente: convocou os netos para lhes transmitir a tradição artesanal. Mas não se tratou de uma transmissão pura e simples: ela preparou um ambiente ritual - awê, cauim e peixe na patioba - no interior do qual ocorreu a transmissão, prática (agulhas, sementes e linhas) e teórica (à medida que ensinava a confeccionar os colares, relembrava como havia sido o seu aprendizado, exortando-os a não esquecerem o legado dos mais velhos). A mesma atitude foi observada em relação ao ritual Awê, ao cauim e ao peixe.

Outros aspectos importantes dessa cadeia estão nas diversas formas de uso das matérias-primas, na relação com a ecologia local e na maneira como os artefatos circulam entre as aldeias e além delas, conforme descreveremos, a seguir, começando por um pequeno painel da sua variedade.

\section{Quais ADereços SÃo feitos Pelos Pataxó?}

Seguindo as Figuras abaixo, é possível saber um pouco sobre a variedade dos adereços produzidos pelos Pataxó nos dias atuais. São tangas, cocares, colares, dentre outros. São muitos e não daria para apresentar, neste espaço, todos os modelos. Por isso escolhi alguns dos mais comuns entre os que são produzidos.
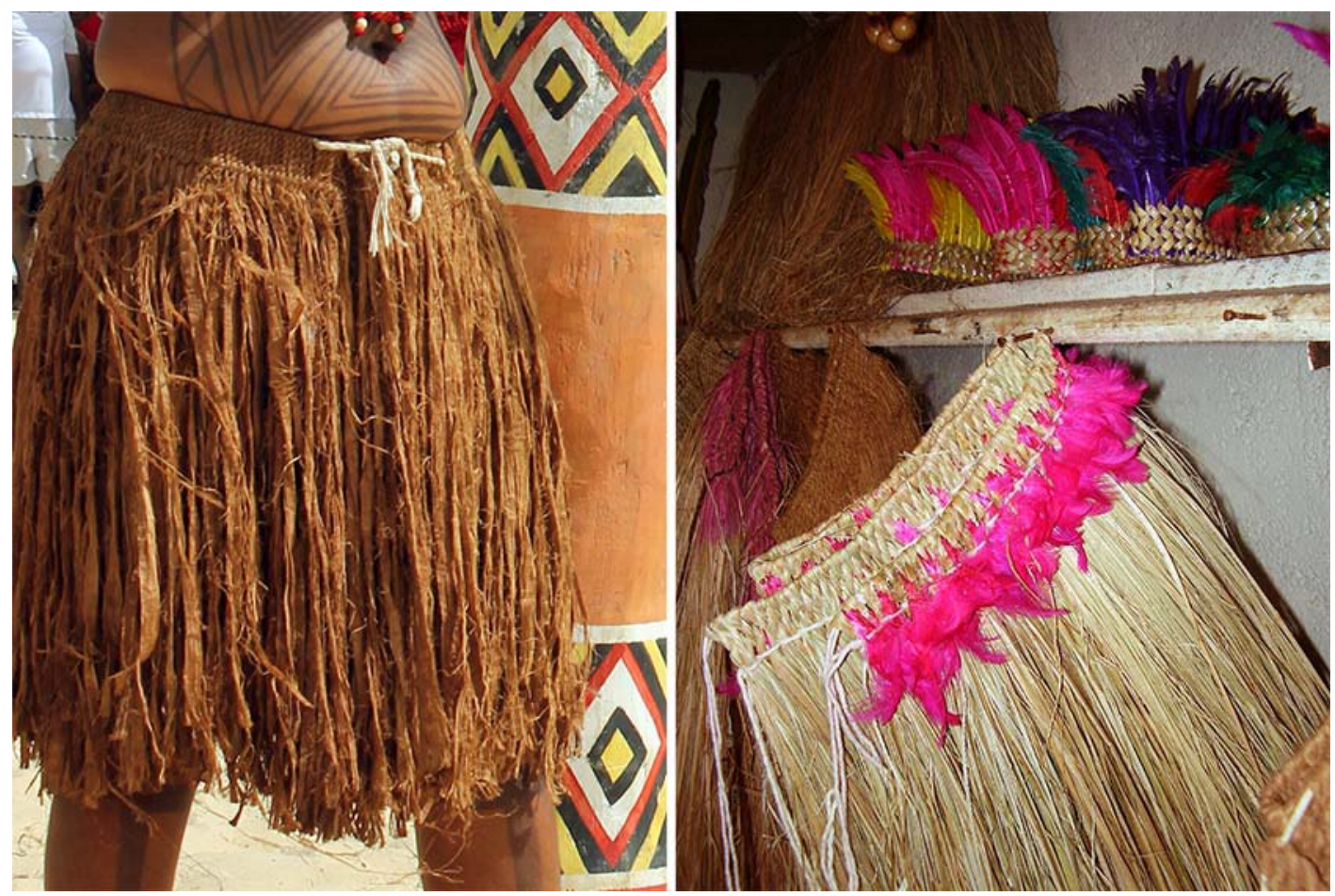

Figura 2-3. Tanga de Biriba ou estopa (2012). Tanga de taboa exposta para venda (2011). ${ }^{8}$

8 Todas as fotografias elaboradas pela autora. 
A tanga ou tupisay é uma espécie de saia feita com fibras soltas amarradas a uma corda, que envolve a cintura. Não há muita variedade, tendo em vista que é feita apenas de duas matérias-primas diferentes, ambas de origem vegetal, como mostram as Figuras 2 e 3. As diferenças mais perceptíveis estão relacionadas ao tamanho, pois há pessoas que gostam e usam as mais longas, abaixo dos joelhos, e há outras que as usam mais curtas, acima dos joelhos. A tanga da biriba é macia e maleável, ao passo que a tanga de taboa já não é tão flexível assim. A segunda é a mais procurada pelos turistas, sendo vendida acompanhada por um colar, um cocar, um bracelete e uma tornozeleira. Um conjunto que pode ser encontrado com penas de diversas cores.
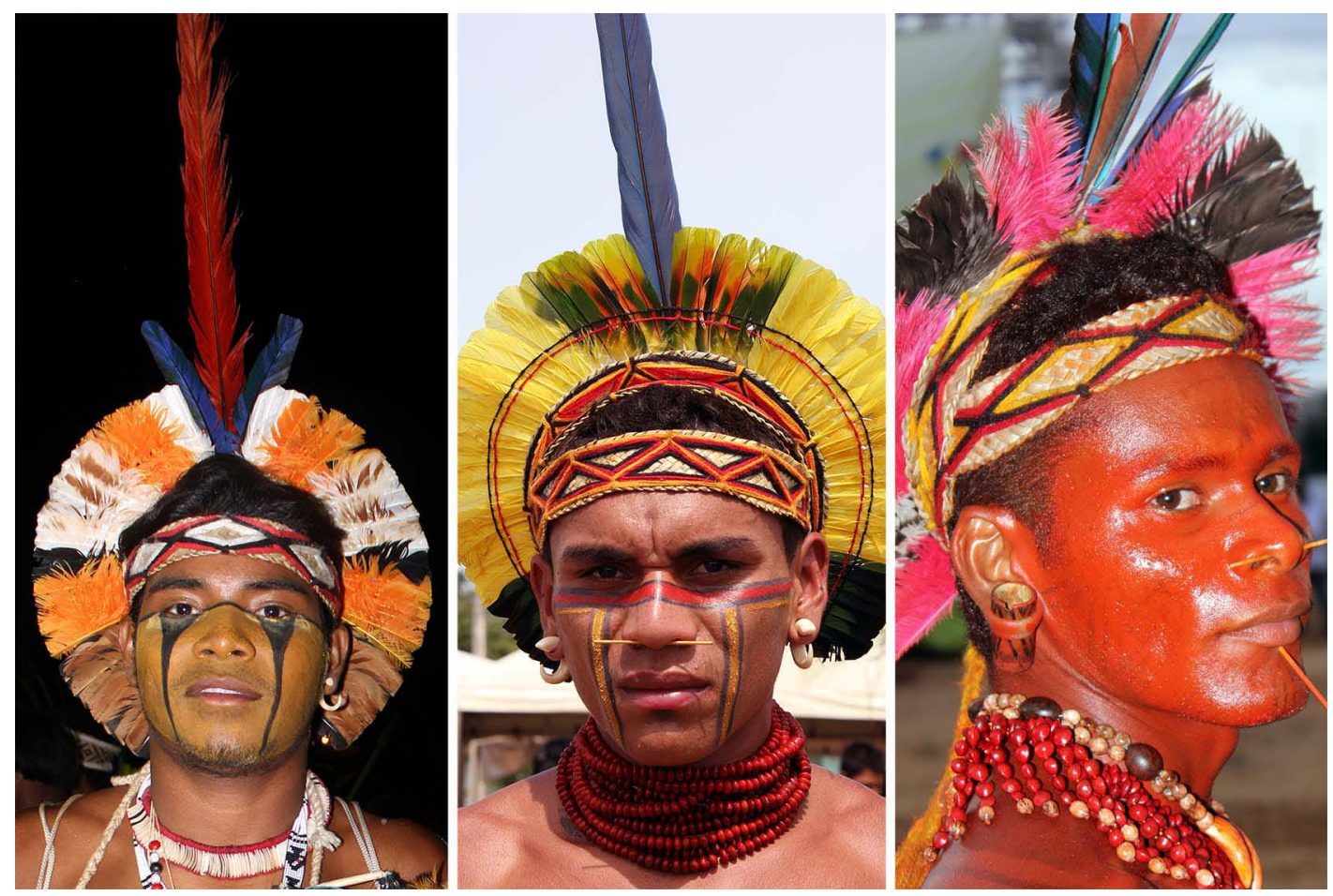

Figura 4-6. Pataxó durante os Jogos Nacionais em Tocantins (2011).

O cocar é um adereço usado na cabeça, confeccionado com penas apoiadas em uma trama, geralmente feita com a palha de uma palmeira conhecida como aricuri. Mas é possível encontrar outros materiais usados nessa produção, como a taboa que está substituindo as penas em alguns modelos de cocar, como podemos ver nas Figuras 7 e 8. Os cocares são dos adereços que mais apresentam variação, mediante pequenos detalhes perceptíveis principalmente na combinação das cores das penas e nos grafismos tecidos nas tranças que sustentam as penas ou outro material componente, tais como nas Figuras seguintes 4-7.

As Figuras abaixo permitem perceber que as mulheres também usam cocares grandes, muito similares aos cocares masculinos, mas o que é mais comum entre elas é o uso dos cocares tipo coroinha, que podem ser usados com a parte das penas para baixo ou para cima. Alguns possuem, na parte traseira, linhas enfeitadas com penas. A variedade desse tipo de cocar evidencia-se mais pelas cores das penas, algumas das quais são penas de galinha caipira: esses preservam a cor natural das penas, ao passo que outros são feitos com penas de galinhas de

9 Palavra em patxohã para tanga ou roupa. 
granja, passíveis de serem encontrados em várias cores, pois as penas são tingidas com anilina, tal como na Figura 13.
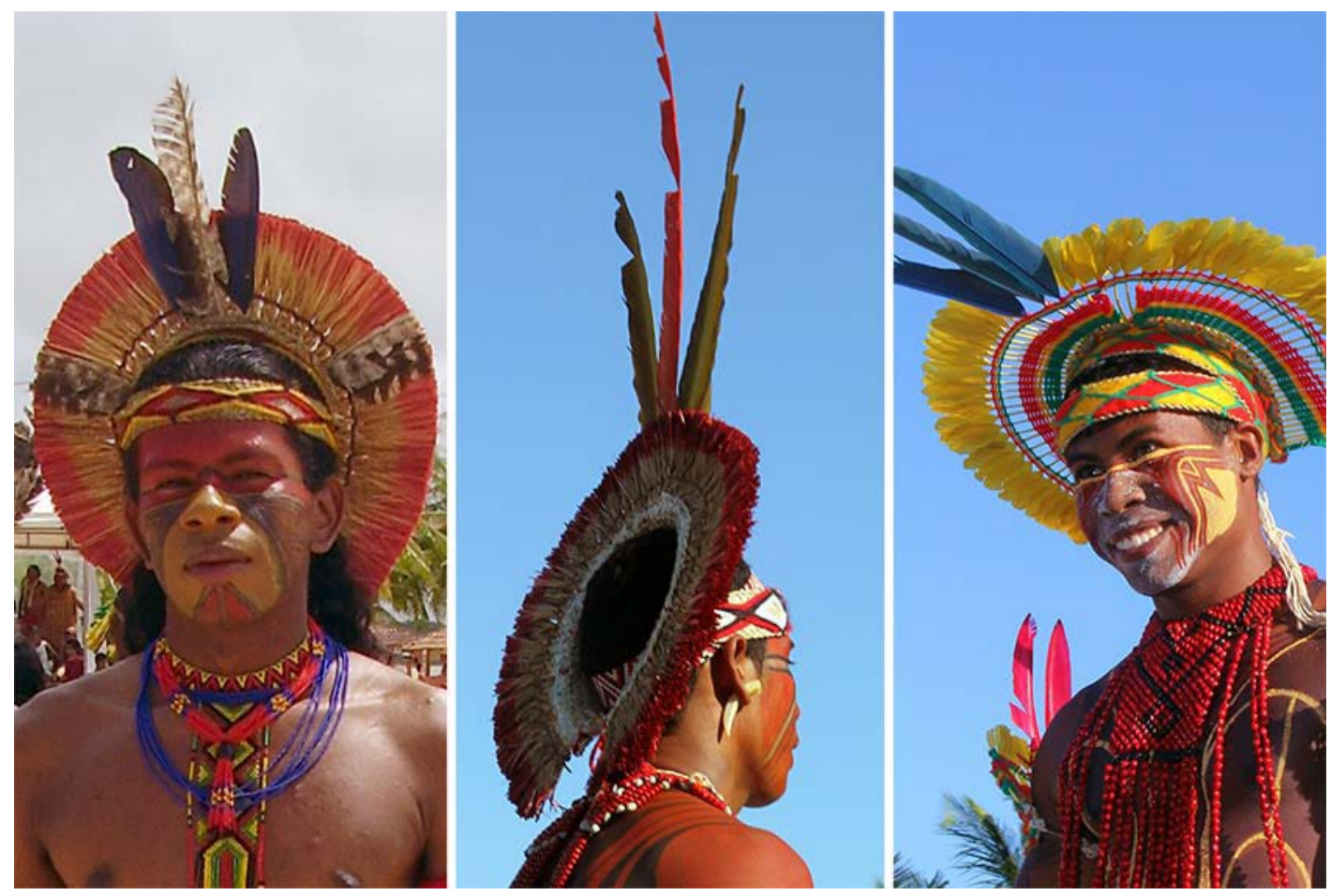

Figura 7-9. Oiti com cocar de taboa (2010). Cocar de taboa (2012). Pedro com cocar que tem aberturas entre as penas feito por Gilson (2012).
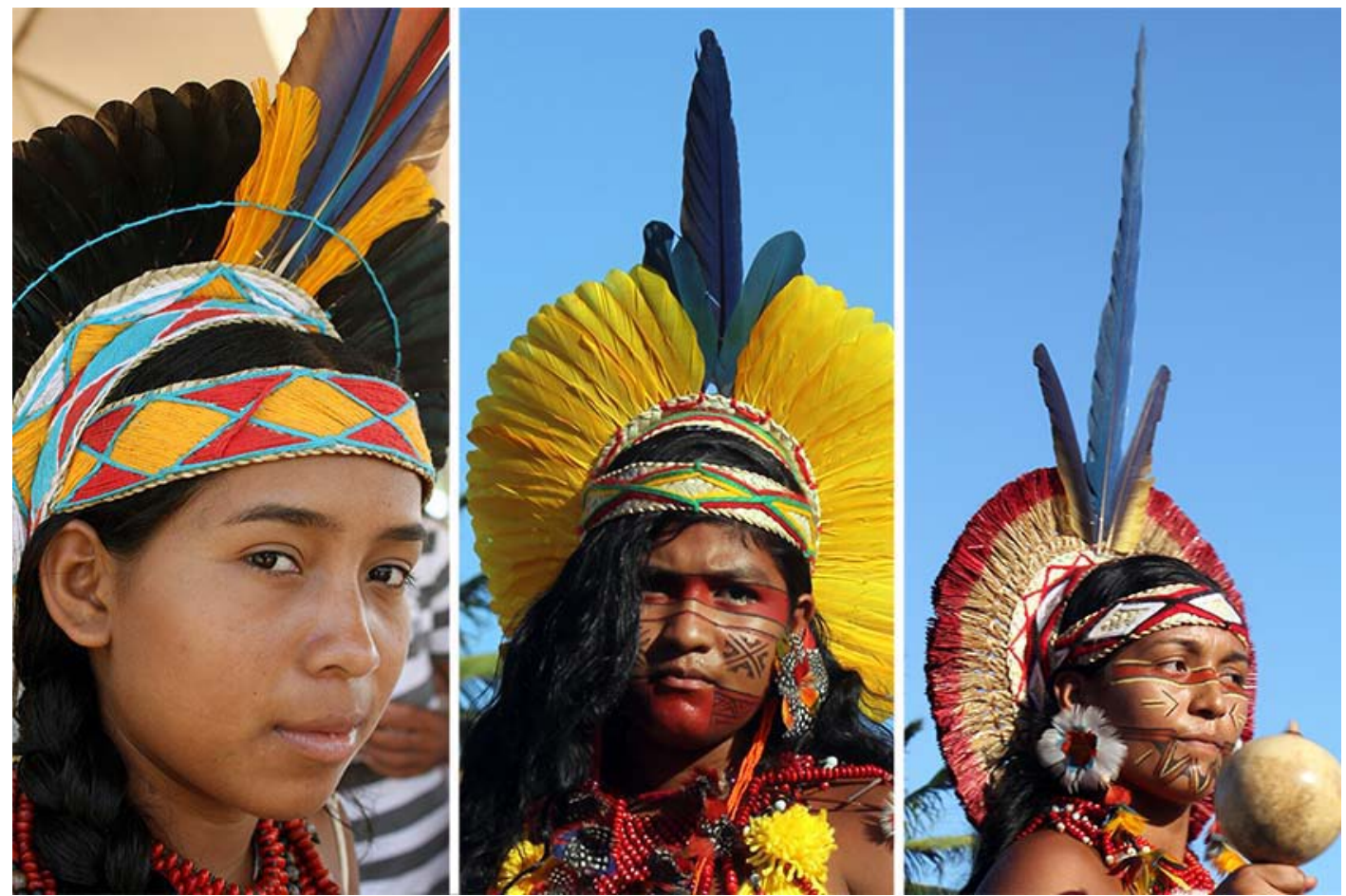

Figura 10-12. Jovem Pataxó, durante participação dos Jogos Nacionais em Tocantins (2011). Jovem Pataxó durante desfile da ihé baixú nos Jogos Pataxó de Coroa Vermelha (2012). Jovem Pataxó com cocar de taboa, durante desfile ihé baixú nos Jogos Pataxó de Coroa Vermelha (2012). 


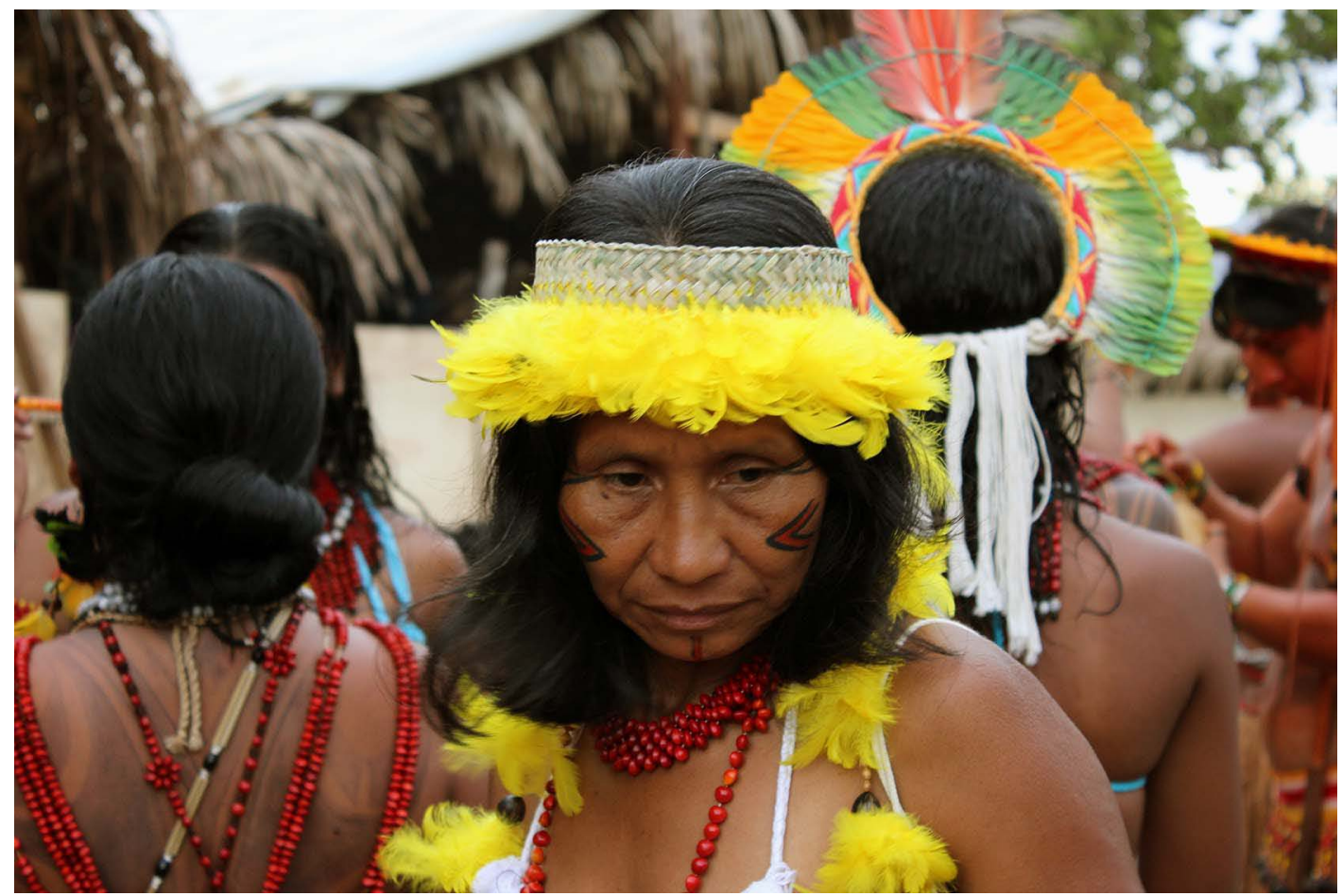

Figura 13. Meruka Pataxó durante participação nos Jogos Nacionais em Tocantins, em 2011.

Com relação aos colares, se levarmos em consideração as cores, a variedade e a disposição das sementes, notaremos que são incontáveis os modelos em circulação.

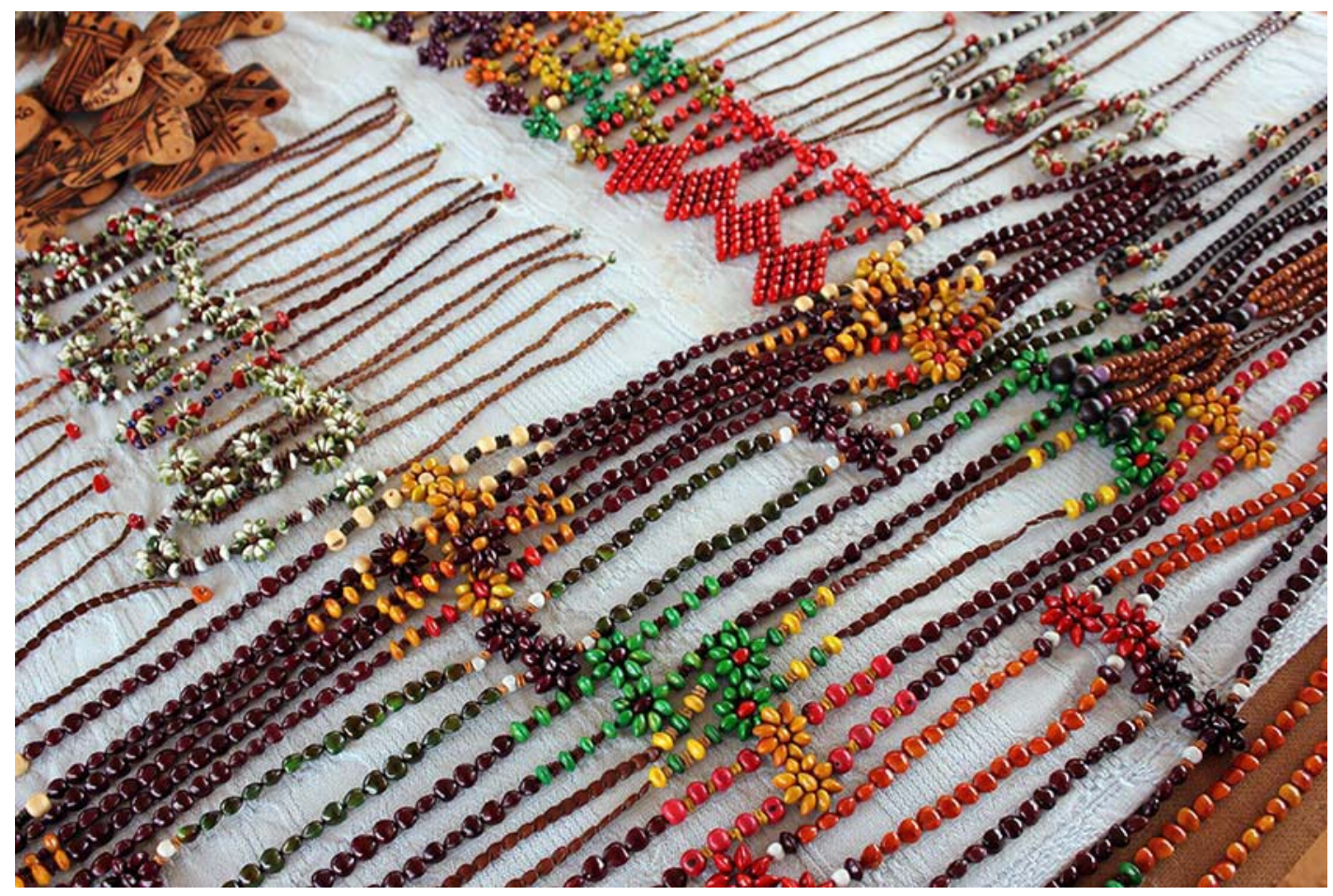

Figura 14. Colares feitos de diversas sementes expostos em uma mesa para venda, 2011.

Os colares produzidos para a venda (Figura 14) são mais simples que os colares usados para adornar os corpos indígenas em dias especiais (Figuras 15 e 16). O colar é a peça final na 
composição dos adereços, usado, geralmente, em volta do pescoço, mas agora também é possível encontrarmos grandes colares que, além de terem uma volta que passa ao redor do pescoço, também se alongam e passam por debaixo dos braços, como mostra a Figura 15. Podemos dizer que esses são modelos mais novos, confeccionados mais para uso dos pataxós, sendo, portanto, mais comercializados internamente.
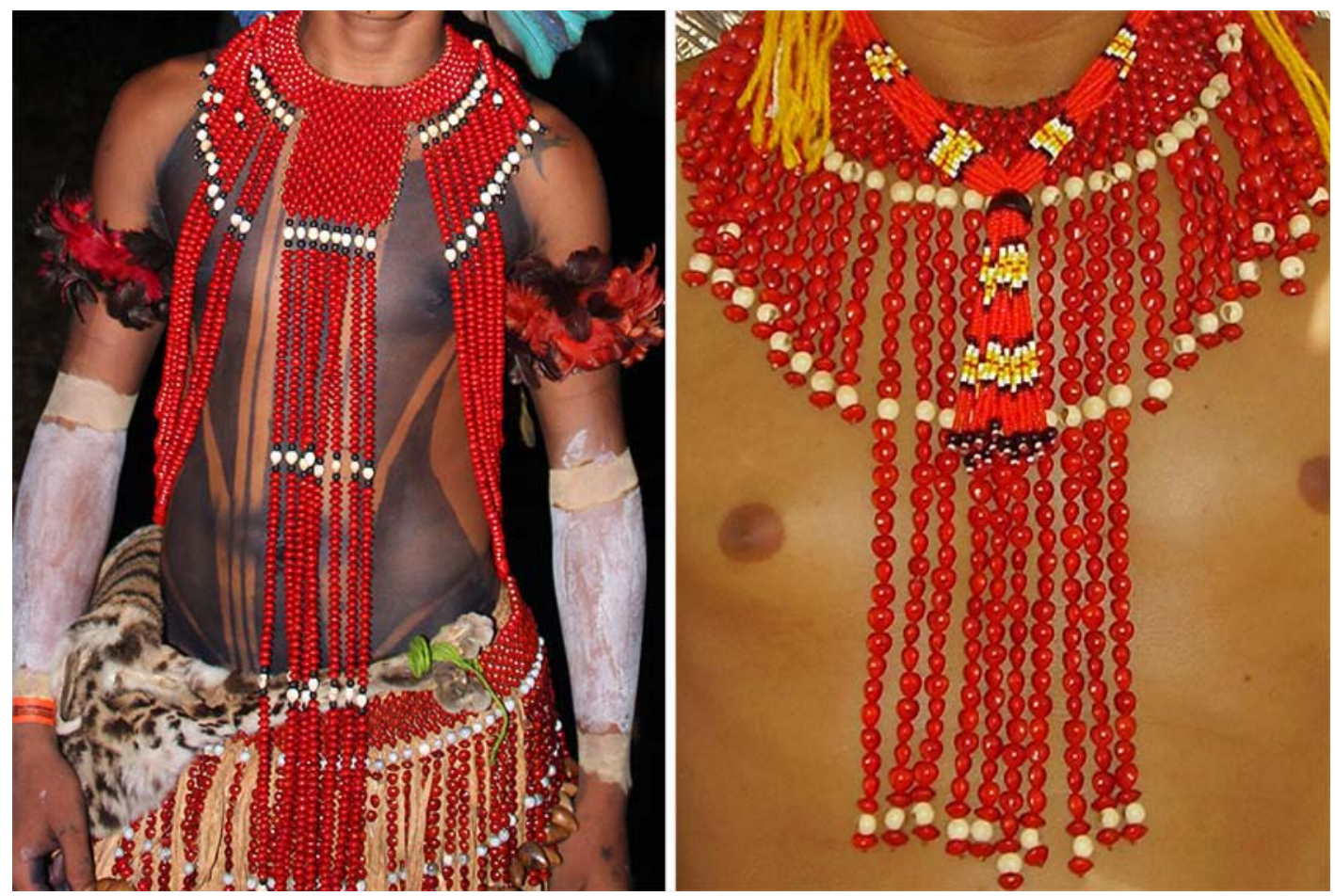

Figura 15-16. Colar Pataxó que envolve o pescoço e passa sob os braços (2012). Colar Pataxó feito de tento, usado por um homem (2012).

Outro adereço que, ultimamente, tem ganhado espaço entre os Pataxó é o cinto, que pode ser usado tanto por homens quanto por mulheres. Os Pataxó já usavam o cinto no passado, porém o seu uso se intensificou no presente. Atualmente pode ser encontrado em diversos modelos e também com variedade de matéria-prima, geralmente as mesmas utilizadas em outros adereços, sendo mais comum o de linhas de crochê, fios de lã e penas.

Embora exista uma grande diversidade de adereços Pataxó que são diferenciados pelas cores e materiais usados, eles possuem uma unidade que os distingue de adereços produzidos por outros povos indígenas. Assim, embora outros indígenas compartilhem o uso de determinados adereços, é possível distinguir um Pataxó em meio a outros indígenas mediante a composição do seu traje, i.e., cocar, tanga e colares. Ademais, costumam usar penas nas cores vermelha, verde, amarela e branca, o que termina constituindo um padrão Pataxó composto por vários fatores que se combinam desde a produção. 


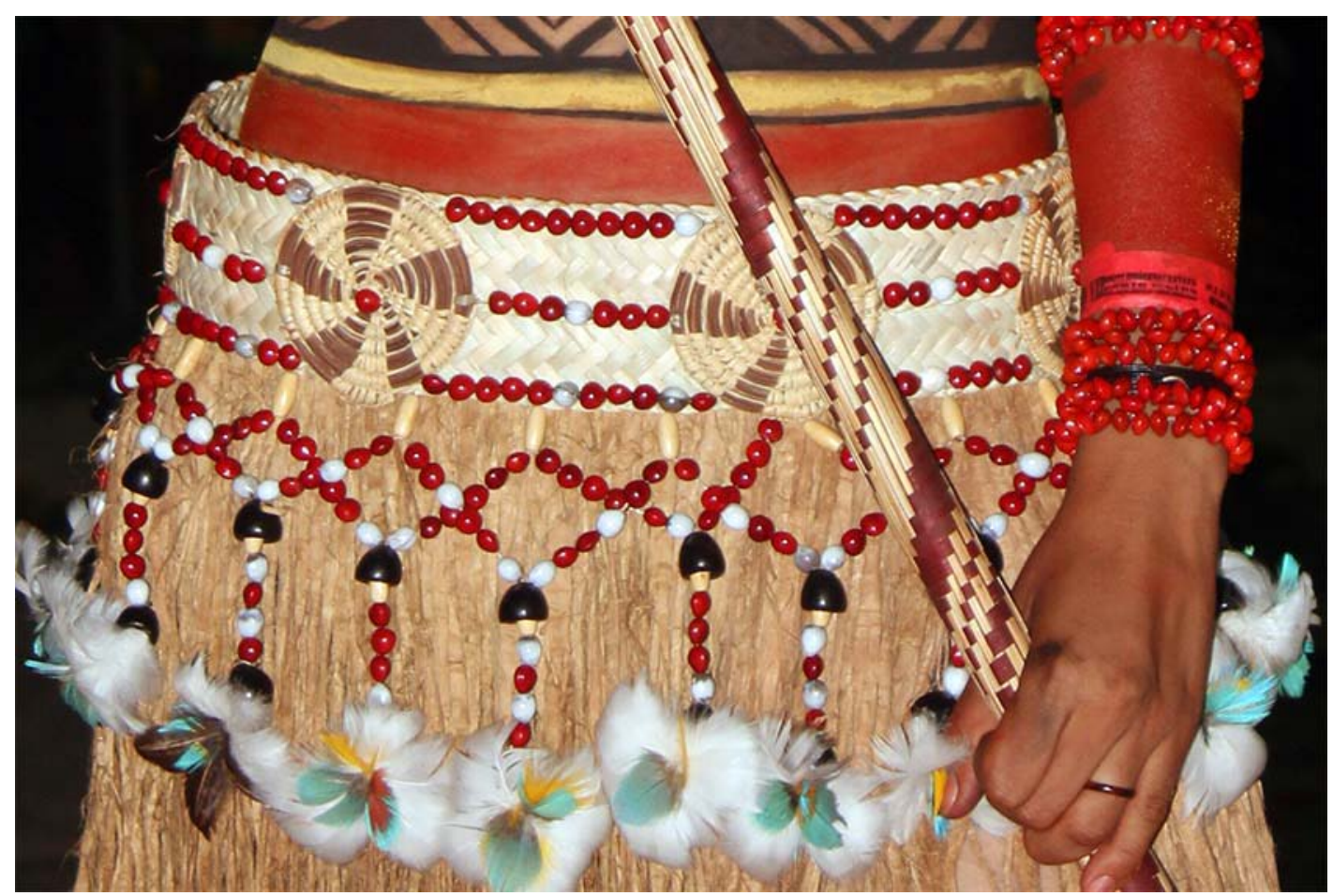

Figura 17. Cinto feito com a trança do aricuri, enfeitado com sementes e penas e detalhes de piaçava.

\section{QUem PROdUZ OS ADEREÇOS?}

Os adereços são feitos por homens, mulheres e crianças. A maioria é produzida por adultos, mas as crianças também participam das atividades, acompanhando os pais, mesmo que brincando. Os mais produzidos pelas crianças são os colares. As mulheres se destacam na produção de peças menores, tais como os colares, brincos, pulseiras, cintos, tornozeleiras, braceletes e cocares femininos, enquanto os homens na produção dos cocares masculinos e das tangas. No entanto, a divisão social da produção não é rígida, havendo mulheres que produzem cocares e tangas, assim como homens que se esmeram na produção de adereços confeccionados, predominantemente, pelas mulheres, como os colares. Não há, assim, predominância de regras, mas apenas o desenvolvimento de habilidades para a confecção de determinados adornos, considerados também os fatores relacionados à extração da matéria prima e ao ensino transmitido pela família.

Durante as visitas que fiz às aldeias, no decorrer da pesquisa de campo, tive a oportunidade de conhecer pessoas que se dedicam à produção de adereços, dentre as quais Dona Senhorinha, da Aldeia Pé do Monte. Quando a visitei, ela estava confeccionando uma tanga de estopa, o que não é uma atividade comum entre as mulheres, talvez devido à dificuldade de extração do que chamamos "pano da estopa". Apesar dessa dificuldade, em outras aldeias, algumas mulheres também tecem a tanga, mesmo que na maioria dos casos sejam os homens os extratores da fibra.

Ao se considerar a variedade de adereços e matérias-primas empregadas, conclui-se que há muita gente envolvida com essa produção. No que concerne aos brincos, braceletes, pulseiras e cintos há sempre um número maior de pessoas que dominam a sua manufatura. Nesses casos, geralmente elas têm essa atividade como a principal fonte de renda, tal como ocorre com a famí- 
lia de Ecleides, residente em Coroa Vermelha. Ela ajuda a mãe na produção dos conjuntos das tangas de taboa ${ }^{10}$ e outros adereços menores, tais como colares, presilhas, etc. Outras famílias e indivíduos, mesmo tendo outras formas de sustento ou profissão, também fazem adereços para vender ou para, eventualmente, o próprio uso, tais como o professor Gilson, que leciona na Escola Indígena Pataxó de Coroa Vermelha e ainda encontra tempo para confeccionar alguns cocares; Anderson, neto de Zabelê, que não tem na produção de adereços sua fonte principal de renda, mas produz cocares sempre que recebe alguma encomenda; e Voltairis, professor de Patxohã da Aldeia Pequi, que também se encaixa nessa situação. Meu pai, Wilson, dedica-se diariamente à produção de cocares que minha mãe expõe na loja do Comércio Indígena ${ }^{11}$, para vender aos turistas, mas se aparecer algum índio querendo comprar, ele vende, não obstante por um preço bem mais baixo, principalmente quando é para o índio revender.

Muitas pessoas dominam a produção de determinados adereços e conhecem as matérias-primas, pois produzem constantemente; outros, muito raramente se dedicam à atividade; e finalmente há quem já tenha produzido muito, tendo interrompido em um determinado tempo. São pessoas que sabem fazer, mas não fazem. Podemos dizer que o número de pessoas que sabem fazer é bem maior se comparado ao dos produtores regulares. Há ainda quem tenha certa habilidade para produzir um determinado adereço, ou que saiba produzir vários, mas que prefere se dedicar apenas a alguns tipos, evidenciando tendência à certa especialização.

Em algumas aldeias concentra-se uma maior produção de determinados adereços. Esse fato se deve, muitas vezes, à disponibilidade de matéria-prima encontrada em cada lugar. Coroa Vermelha, por exemplo, concentra a produção de cocares devido à maior facilidade de encontrar as penas, que são compradas ou adquiridas, gratuitamente, nas granjas. Em Barra Velha concentra-se a maior produção de colares, devido à grande variedade de sementes encontrada na aldeia e à habilidade das mulheres.

As famílias que têm como principal fonte de subsistência a produção de adereços tendem a variar a produção para incrementar as vendas. A manufatura de determinados produtos tem grande influência na família, uma espécie de aprendizado que podemos considerar como uma herança familiar. Em Coroa Vermelha, Ecleides ajuda a mãe na produção de uma variedade de objetos, dentre os quais a zarabatana ${ }^{12}$, jogo de arco e flecha ${ }^{13}$, presilhas, palito de cabelo e os conjuntos de tanga, anteriormente mencionados. Quando lhe perguntei se a sua mãe fazia adereços há muito tempo, ela respondeu que Benedita Sena já nasceu fazendo, uma vez que fazia desde quando morava na Aldeia Trevo do Parque, pois aprendera com Dona Tereza, sua avó. Ecleides diz que, no momento, sua avó não produz mais, pois agora vive da aposentadoria, contudo seus tios, que moram na Aldeia Trevo do Parque, constantemente vêm à Coroa Vermelha fazer entrega desses mesmos produtos que ela e sua mãe confeccionam.

10 Conjunto de tanga de taboa é um kit composto por um cocar, um colar, um bracelete, uma tornozeleira e uma tanga, enfeitados com penas de galinha de granja tingidas. Pode ser encontrado sob diversas cores.

11 Também conhecido como Shopping Indígena, o comércio de artesanato fica localizado no Parque Indígena, uma área próxima à praia de Coroa Vermelha. Wilson não é Pataxó, mas por viver na mesma região, convive e mantém contato com os Pataxó desde a infância.

12 Feita de taboca, uma espécie de bambu, a zarabatana é um arma de sopro acompanhada de pequenas flechas usadas, hoje, por alguns povos indígenas, para abater pássaros.

13 Um kit feito pra venda composto por um pequeno arco, um bajaú, com algumas flechas e uma pequena lança de pati. 


\section{MatéRIAS-PRIMAS USADAS}

Os Pataxó sempre usufruíram da extração de vegetais para a produção de diversos objetos, tanto para uso pessoal quanto doméstico, fruto da transmissão de saberes dos mais velhos aos mais jovens. Daí que os adereços Pataxó, ainda nos dias atuais, sejam, em sua maioria, confeccionados a partir da extração de matérias-primas naturais.

Os materiais utilizados para a produção dos adereços são diversos. E, embora os Pataxó empreguem também materiais industrializados, não deixaram de utilizar as tradicionais matérias primas, dentre as quais a trança do aricuri, a taboa, a estopa, as penas, e as sementes que encontramos em grande variedade, em geral sementes de frutos não comestíveis. As mais usadas são a juerana, o pariri, o tingui, o maui, o mata-passo, o fedegoso, o olho de pombo, a salsa, o sabão de macaco e o tento, também conhecido como pau-brasil.

Dos novos materiais que têm ganhado espaço na produção dos adereços, estão as linhas de lã e de crochê, usadas principalmente na confecção dos bustiês e dos cintos, o que possibilita a combinação com as cores dos cocares, como podemos observar na foto abaixo:

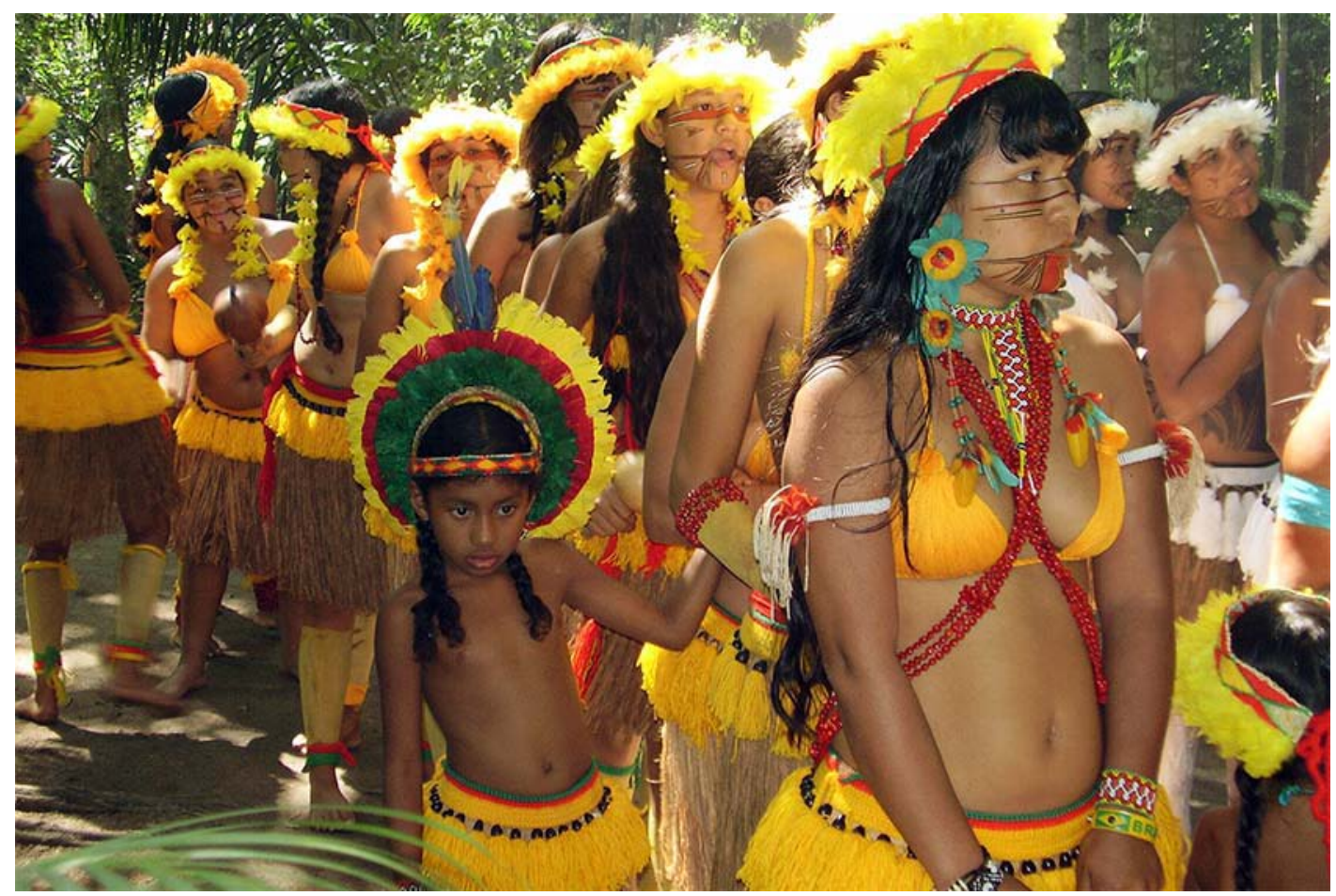

Figura 18. Jovens Pataxós durante a festa do Araguaksã, Reserva da Jaqueira (2010).

As matérias-primas procedem de vários lugares. Cada aldeia possui diferentes fontes de coleta e obtenção de materiais. Em Coroa Vermelha os Pataxó de outras aldeias conseguem alguns materiais, principalmente a trança feita da palha do aricuri, usada para confeccionar os cocares. Entretanto, a trança ali encontrada não é produzida pelos índios, mas comprada junto aos regionais e revendidas em suas lojas de artesanato.

Até o século XX a produção da trança do aricuri era muito comum, feita tanto por homens quanto mulheres Pataxó, para a confecção de chapéus e cocares. Atualmente poucas pessoas 
ainda tecem essa trança. Entre as aldeias que visitei, tive a oportunidade de encontrar duas senhoras, em aldeias diferentes, que ainda teciam a palha do aricuri para fazer tranças, vendidas na própria aldeia: Dona Zabelê, na Aldeia Tibá, e Dona Senhorinha, na Aldeia Pé do Monte que, por coincidência, aprendeu com Zabelê. Mas não é raro encontrarmos pessoas, por todas as aldeias, que fazem referência à trança, usando a seguinte frase: "minha vó fazia". Hoje em dia, embora saibam fazer, muitos velhos já não produzem mais, e eu suponho que a dificuldade de encontrar a matéria-prima esteja determinando o seu desinteresse, bem como a comodidade de encontrá-la já pronta e por um baixo custo não desperta nas novas gerações o interesse em aprender. Voltairis, da Aldeia Pequi, afirma que comprava na mão de sua prima, que comercializava as tranças no comércio indígena, em Coroa Vermelha. Por sua vez, Cristiane, da Aldeia Cay, e Anderson, da Aldeia Tibá, dizem que compram trança em Coroa Vermelha, mas também compravam "na mão" de Zabelê, quando ela tinha em estoque.

Ao visitar a Aldeia Tibá tive a oportunidade de comprar um rolo da trança feita por Dona Zabelê, que observou, na ocasião, que seu filho tinha conseguido as palhas com muita dificuldade: "Aqui tá difícil, menina, quais num tem não, o pessoal chegaro aí, cabaro com tudo, essas palha que fiz aí a gente pegou lá no... Onde cê pegou?” perguntou, dirigindo-se ao seu filho que participava da conversa.

Lá no Moreira. É na beira da praia só que a maioria já é tudo pousada, só que a gente procura, tem aqueles lotes que ainda tá sem construir é onde agente tira um pouco, já no ponto da falesi também [...] a gente pega, tem um pedaço lá a gente vai tirando. O lugar de pousada que eles tem a propriedade mesmo, eles num deixa tirar não. (informação verbal) $)^{14}$.

Muitas vezes são esses e outros fatores que acabam interferindo na produção dos adereços Pataxó, levando-os a recorrer até mesmo a materiais industrializados para suprir a falta de determinadas matérias-primas.

As linhas de tucum, anteriormente usadas para produzir os colares, há alguns anos foram substituídas pelas linhas enceradas, industrializadas, à semelhança de fios de plástico encerados. Não foi possível descobrir se o motivo para essa nova utilização foi a escassez do tucum na região ou a facilidade de acesso às linhas industrializadas. Suponho que os dois fatores possam estar influenciando, já que a confecção da corda de tucum é um pouco complexa. Muitos índios devem saber prepará-la, mas a facilidade de comprar uma corda já pronta faz com que o tucum entre em desuso. Em Coroa Vermelha, por exemplo, sei que não há ninguém que trabalhe com a produção ou venda dessa corda, embora haja quem saiba tecê-la. Suponho que a última moradora em Coroa que produzia a corda de tucum, tanto para vender quanto para fazer os seus colares, porém em pequenas quantidades, era Dona Rosário, já falecida. Da sua produção adquiri algumas dessas cordas para fazer algumas pulseiras: ela vendia os fios do tamanho correspondente à feitura de um colar. Hoje, em Coroa, quando queremos confeccionar um colar, vamos diretamente ao armarinho comprar um rolo de linha encerada. Essa prática também se repete em outras aldeias Pataxó.

A dificuldade de encontrar penas grandes para fazer cocares maiores tem, por sua vez, compelido os Pataxó a recorrerem a outros meios, como, por exemplo, usar a taboa no lugar das penas, embora, em geral, usem penas de galinha de granja que, por serem brancas, podem ser tingidas em várias cores, principalmente na produção dos cocares femininos. Outra alternativa

14 Entrevista concedida em março de 2011, na Aldeia Tibá. 
encontrada, por alguns pataxós, para manterem o estoque de penas em casa é a criação de aves, como galinhas e patos. Naiara, que mora em Coroa Vermelha, cria, em um cercado no fundo da sua casa, alguns patos de plumagem branca e, sempre que necessita, deles retira penas. $\mathrm{Na}$ preparação dos adereços para os Jogos Pataxó pude presenciar essa cena, pois minhas irmãs precisavam de penas para a produção dos cintos e obtiveram-nas através de Naiara, que as retirou dos seus patos, sem precisar abatê-los.

Como vimos anteriormente, para driblar a escassez de matéria-prima, os Pataxó recorrem até mesmo a espaços externos às aldeias. Loro, que costuma fazer os cocares de taboa para os Jogos Pataxó, diz que há dois locais externos nos quais a população de Coroa Vermelha coleta a taboa, sendo um próximo a um bairro conhecido como "Casinhas", e o outro na estrada que liga Coroa Vermelha a Porto Seguro, próximo a uma praia conhecida como Ponta Grande, onde a matéria-prima pode ser encontrada em abundância.

\section{Como SE FAZ}

Cada adereço produzido pelos Pataxó constitui parte de um longo processo que compreende desde a extração, coleta ou compra da matéria-prima, que pode ser simples, mas em geral é bem complexo, até a elaboração do objeto propriamente dito.

Para a confecção dos colares despende-se um bom tempo no preparo das sementes até deixá-las no ponto certo, considerando-se que cada uma delas tem uma propriedade particular que interfere nesse preparo. Por exemplo, é necessário saber o tempo certo em que a semente está pronta para ser colhida, de modo que mais tarde ela não venha a murchar. Outro fator que vale destacar é que nem todas as sementes podem ser encontradas ao longo do ano, o que quer dizer que a confecção dos colares acompanha o ciclo da natureza. Podemos, assim, encontrar uma abundante quantidade de colares de uma determinada semente em algumas épocas do ano. Portanto, a produção de cada adereço é limitada também pela matéria-prima disponível.

No caso dos cocares grandes é necessário reunir uma boa quantidade de penas. E quando essas são compradas ou obtidas nas granjas, vêm sujas, tendo que ser lavadas, tingidas e, na sequência, selecionadas apenas as maiores, geralmente as penas da asa. Um aspecto importante na produção desses cocares maiores, que requer a necessária atenção, é a curvatura natural que as penas, por serem da asa, possuem, curvaturas para a direita e para a esquerda. É preciso, então, atentar para as penas que serão dispostas dos dois lados, de modo a observar a inclinação natural de cada uma. A produção do cocar inicia-se, basicamente, dispondo-se as penas em uma única corda, que unirá todas pelo bico, ou seja, pela parte em que não há plumagem, mas apenas o "talo". Em seguida, deve-se passar uma linha na metade de cada pena, costurando-se uma na outra, para que o cocar se mantenha firme. Nesse ponto já temos um cocar simples. Agora é só fixá-lo na trança do aricuri, depois colocar mais uma trança para apoiar na fronte, possibilitando que o cocar fique mais aberto.

Como observamos no início desta seção, a produção de um adereço Pataxó não se limita apenas ao processo de montagem ou tecimento da peça, mas compreende desde a extração da matéria-prima, que pode requerer maior ou menor esforço do produtor, na dependência da sua 
localização. Voltairis, anteriormente referido, relata, com detalhes, como é o processo de confecção de uma tanga de biriba:

Pra fazer uma tanga é o seguinte: tem que primeiro fazer uma inxó que é de madeira, tem que ser uma madeira resistente pra que ela não possa pocar ou aliás lascar na hora de tá batendo lá na madeira. A melhor é feita de braúna. Depois da inxó pronta aí sim que vai pra mata. Tem que encontrar a biriba que é uma madeira. Você tem que encontrar ela bem certinha, ela com alguns caroços ou aliás nós, ela não presta, não serve.

Dependendo do local, por que tem biriba as vez que tá num local lá embaixo no barranco, num buqueirão que a gente fala,já tem outras que fica na chã em cima. Quando ela é na chã a gente pode ficar no chão mesmo, mas quando é lá no brejo, tem fazer um jurá pra poder a gente subir e tirar.. [...] Se for pra criança você tira de uns quatro palmo, agora se for pra adulto é mais uns dez palmos. E aí tem um processo que a biriba é o seguinte se for tirar ela com facão, ela não sai a fibra assim tipo macia, se for de facão ela sai assim tipo uma casca. A inxó serve pra isso, pra ela ir machucando a madeira pra ir saindo as fibra mole, ir fofando. E a partir de que tira lá, aí sim, traga pra casa e deixa ela um pouquinho no sol para poder secar um pouco. Se for fazer molhado acaba manchando a roupa, até mesmo a nóida na sua mão ela acaba deixando. E aí depois de seca é só desfiar ela, tem uma parte tipo da casca que ela fica ruim e não serve, então a parte de dentro que é a fibra macia aí que serve pra tecer a tanga (informação verbal) ${ }^{15}$.

\section{Comercialização dos ADereços}

Os adereços produzidos são vendidos tanto para pessoas da própria aldeia quanto para pessoas de fora, normalmente turistas. Há, no entanto, uma diferença: quando a venda é para o próprio parente, o preço é mais baixo, ao passo que para os turistas um pouco mais alto. $\mathrm{O}$ preço para revenda também é mais em conta. Anderson, da Aldeia Tibá, comentou que para os parentes ele vende um cocar grande a trinta reais e para os turistas ele pede até cento e cinquenta reais, sendo o preço mínimo setenta reais.

As famílias que se dedicam à produção artesanal em Coroa Vermelha vendem no atacado e varejo, tanto para os comerciantes indígenas quanto para os não indígenas. Ecleides, porém, diz que os conjuntos de tangas que ela e sua mãe confeccionam, dificilmente vendem a varejo, e no atacado transacionam mais para comerciantes externos, entre os quais um comerciante de Porto Seguro e outro de Trancoso.

Nem todas as famílias que estão envolvidas com a produção e venda dos adereços possuem lojas na área do Parque Indígena, o que se deve a vários fatores: alguns nunca ganharam uma loja; outros ganharam e, passado certo tempo, venderam; e outros, por não terem condições de manter a loja recebida, alugaram-na, para garantir, assim, um valor fixo mensalmente. Por outro lado, nem todas as pessoas que têm um ponto de venda no comércio indígena, produzem o que vendem, ou seja, a maioria compra de outros índios que se dedicam mais à produção. E aqueles que produzem um determinado adereço e têm loja, sempre colocam outros produtos para venda, de modo a garantirem alguma venda diária, facultando ao turista interessar-se e comprar um artigo ou outro.

15 Entrevista concedida por Voltairis - Irisnan Pataxó, durante pesquisa de campo na Aldeia Pequi, realizada em fevereiro de 2011. 
Dos adereços Pataxó, os que mais são comprados pelos não índios são os colares, havendo também uma grande demanda por outros produtos, tais como brincos, palitos de cabelo e presilhas. A Aldeia Barra Velha é a maior fonte da produção de colares e, como tal, exporta para as outras aldeias Pataxó.

Com relação às tangas e cocares, os mais comprados pelos não índios são os conjuntos já citados anteriormente que, por serem compostos de um cocar mais simples e tanga de taboa, são bem mais baratos do que uma tanga de estopa e um cocar maior. Esse kit pode ser encontrado nas lojas do Parque Indígena, assim como entre os índios que vendem nas praias de Coroa Vermelha e da região de Porto Seguro. No local denominado Passarela do Álcool, em Porto Seguro, também é possível encontrar aproximadamente três barracas que vendem esses conjuntos.

A comercialização dos adereços Pataxó está estreitamente ligada à venda de outros objetos produzidos por esse povo. E se estende a vários espaços, pois sendo uma atividade que rege a economia da maioria das aldeias, "obriga" os Pataxó a se deslocarem, com frequência, para garantir a sua sobrevivência. São vendidos nas próprias aldeias e nas praias da região, principalmente aquelas mais próximas, como as praias de Caraíva, Trancoso, Arraial D’Ajuda, Coroa Vermelha, Porto Seguro, Prado e Cumuruxatiba. As vendas nas praias são mais frequentes no verão, quando há um fluxo maior de turistas na região.

A comercialização de artesanato, ainda que dependente de consumidores sazonais, aparece como uma indispensável via de acesso ao mercado, mesmo para os índios das comunidades do Monte Pascoal que, distantes dos principais pontos de comércio, têm que se submeter a intermediários ou se ausentar dos seus locais de moradia na alta estação. (Sampaio 2000: 12).

Durante o inverno, a alternativa é recorrer a lugares mais distantes, mediante a participação em feiras de artesanato e eventos que permitem a comercialização. Mas ainda assim essas oportunidades não podem ser aproveitadas por todos, já que poucas são as famílias que reúnem as condições para custear as viagens, o que submete muitas delas, na maioria dos meses do ano, a uma situação de grave restrição econômica, principalmente em Coroa Vermelha, local em que as famílias dependem, quase que exclusivamente, da venda desses materiais.

\section{UMA TEIA QUE SE TECE}

Embora o povo Pataxó seja um povo grande, disperso territorialmente por várias aldeias, há um fluxo constante entre essas, em decorrência de vários fatores, sejam visitas esporádicas a familiares, migração de famílias entre as aldeias, seja ainda o deslocamento para compra e venda de artesanato. Esses laços constantes entre os pataxós permitem que os adereços circulem, possibilitando que determinadas aldeias, que detêm a fabricação de um tipo específico de adereço, ofereçam o seu produto a outras, aumentando o seu campo de produção e venda. Em Coroa Vermelha, atualmente, por exemplo, é muito difícil encontrar alguém que confeccione a tanga de biriba, embora haja pessoas que saibam fazer, como já mencionado. Mas em decorrência da escassez da matéria-prima há índios que compram essas tangas já confeccionadas de outros índios, estabelecidos nas aldeias de Mata Medonha e Juerana. A escassez de penas também já ocorre, como lembrou Voltairis, que foi compelido a recusar uma encomenda externa de cerca de vinte e cinco cocares devido à falta dessa matéria-prima. 
Os laços de parentesco têm grande influência sobre a circulação dos adereços, pois, em muitos casos, são os primos e tios, moradores de outras aldeias, que viabilizam o trajeto, tanto da matéria prima quanto dos adereços já prontos. Coroa Vermelha é a aldeia que concentra o maior número de famílias Pataxó e a maioria destas tem familiares dispersos por outras aldeias. Isso faz com que ela funcione como o elo com a maioria das aldeias, formando uma grande teia, o que assegura que a dinâmica da criação artística, muito desenvolvida entre os Pataxó de Coroa Vermelha, também alcance as demais aldeias Pataxó.

As redes que entrelaçam as aldeias Pataxó através da circulação dos adereços -- similarmente ao que Bronislaw Malinowski registrou nas Ilhas Trobriand (1984), na Nova Guiné, através do Kula, o intercâmbio ritual ao longo do qual os colares de conchas vermelhas denominados souvala circulavam no sentido horário desse círculo e, na direção oposta (anti-horário), os braceletes confeccionados de conchas brancas, os mwali - ultrapassam as fronteiras da Bahia, estendendo-se aos Pataxó de Minas Gerais.

Em relação aos Pataxó que moram nas aldeias do estado de Minas Gerais, é possível perceber que os seus adereços estão bem conectados com a dinâmica promovida pelos Pataxó da Bahia. Por terem um forte sentimento de pertença ao lugar de onde saíram (Barra Velha), os Pataxó ali estabelecidos mantêm relação também através dos adereços que, na Bahia, são usados, dado demonstrativo de que nem as fronteiras territoriais nem a distância impede a circulação dos adereços, o que assegura uma unidade, ou como poderíamos dizer, um padrão Pataxó. Mas, cabe ressaltar que, não obstante perceba-se a tendência à criação de um padrão, não prevalecem constrangimentos com esse fim, o padrão ou a unidade se constituindo a partir da imagem de uma "comunidade imaginada" (Anderson 1989: 14), que perpassa territórios distintos e distantes.

\section{Conclusão}

Propomos, neste artigo, uma descrição dos adereços Pataxó, compreendendo desde a matéria prima até a comercialização, e destacando, na produção, os processos de aprendizagem que os mais velhos transmitem aos mais jovens, tal como lhes foi, reciprocamente, transmitidos.

Nessa pequena mostra é possível perceber a variedade dos adereços Pataxó, que se desdobra à medida que um novo detalhe é acrescentado, seja uma nova matéria-prima utilizada em um cocar, um colar ou um cinto. Os detalhes, tanto produzidos por matérias-primas de origem vegetal e animal quanto por produtos industrializados, tornam-se significativos e agregam valor aos objetos.

É notável, assim, a grande rede que se tece através da circulação dos adereços, permitindo aos Pataxós se manterem em uma dinâmica constante, de criação de novos modelos, de inserção de novas matérias-primas, facilmente expandidas, uns e outras, às diversas aldeias Pataxó, o que tende a produzir uma certa unidade nos adereços do povo Pataxó, constituída, é claro, por uma enorme variedade... 


\section{RefERÊNCIAS}

Anderson, Benedict. 1989. Nação e nacionalismos. São Paulo, SP: Ática.

Lagrou, E. 2010. "Arte ou artefato? Agência e significado nas artes indígenas." ProaRevista de Antropologia e Arte 02 (1). Acesso em: 23 mar., 2011 (http://www.ifch.unicamp.br/ proa/DebatesII/elslagrou.html).

Malinowski, Bronislaw. 1984. Argonautas do Pacifico Ocidental: um relato do empreendimento $e$ da aventura dos nativos nos arquipélagos da Nova Guiné melanésia. São Paulo: Abril Cultural.

Sampaio, José Augusto L. 2000. "Breve história da presença indígena no extremo sul baiano e a questão do território Pataxó de Monte Pascoal." Pp. 121 - 136 in Política indigenista leste e nordeste brasileiros, organizado por M. A. do E. SANTO. Brasília, DF: Ministério da Justiça/Funai.

\section{THE SPIDER LIVES OF WHAT SHE WEAVES}

This article is based on my dissertation entitled "Art and Identity: Pataxó body adornments", the result of an ethnographic research conducted between 2010-2012, among the Pataxó people from the South of Bahia. The research describes the Pataxó adornments, highlighting processes of learning, production, commercialization and exchange between the different communities, and presents the diversity of the Pataxós artwork.

Keywords: adornments, Pataxó, identity, art. 